\title{
Effects of organic matter content and seedling density for growing bare-root narrow-leaved ash (Fraxinus angustifolia vahl.) seedlings
}

\author{
Cemal FIDAN ${ }^{1}$ \\ ${ }^{I}$ Poplar and Fast-Growing Tree Species Research Institute/Başiskele/Kocaeli/Turkey \\ Corresponding author: cemalfidan@ogm.gov.tr
}

\begin{abstract}
This study was conducted to determine the effect of organic matter (OM) content and seedling density (SD) on achieving the number of quality one-year old bare-root of Narrow-leaved ash (Fraxinus angustifolia Vahl.) seedlings. The seedlings with $\geq 75 \mathrm{~cm}$ and $0.8 \mathrm{~cm}$ root-collar diameter were identified as the quality seedlings. The split plot design was used for the study. Three rates of OM $\left(2 \mathrm{~m}^{3}, 1 \mathrm{~m}^{3}\right.$, and $0 \mathrm{~m}^{3}$ added to 150 -m seedbed) made up as the main treatment. Four SDs $\left(100,75,50\right.$, and 25 seedlings $\left.\mathrm{m}^{-2}\right)$ were used on each of the OM treatment plots. The results have shown that the level of OM and SD had a significant effect on the number of quality seedlings obtained from certain unit area. The maximum quality seedling number (QSN) was obtained from the highest $\left(2 \mathrm{~m}^{3}\right)$ OM treatment plots. The QSN obtained in the densities of 75, 100, 50, and 25 were 38, 38, 33, and 17 , respectively. The QSN in the densities of 75, 100, and 50 that applied within the $2 \mathrm{~m}^{3} \mathrm{OM}$ treatments were in the same group. There was not significant difference between the number of quality seedlings obtained from 1 and $0 \mathrm{~m}^{3} \mathrm{OM}$ treatment plots. It was apparent that, while the productivity of seedbed increased, the number of quality seedlings increased. It suggests that the SD should be adjusted according to the productivity of seedbed. Also, growing seedlings in lower densities are more feasible and economic than higher densities. The SD of 50 with the $2 \mathrm{~m}^{3} \mathrm{OM}$ and the SD of 25 with 1 and $0 \mathrm{~m}^{3} \mathrm{OM}$ are recommended for the practice.
\end{abstract}

Key words: Narrow-leaved ash, organic matter, seedling density, quality seedling

\section{Özet}

$\mathrm{Bu}$ çalışma, organik madde içeriği ve fidan yetiştirme sıklı̆ğını, bir yaşlı ve standart kalitede Dar Yapraklı Dişbudak (Fraxinus angustifolia Vahl.) fidanı elde edilmesi üzerindeki etkilerini belirlemek için yapılmıştır. Kök boğazı çapı $(\mathrm{KBÇ}) \geq 0.8 \mathrm{~cm}$ ve fidan boyu $(\mathrm{FB}) \geq 75 \mathrm{~cm}$ olan $1+0$ yaşlı ve çıplak köklü fidanlar, standart fidan (SF) olarak kabul edilmiştir. Çalışmada bölünmüş parseller deneme deseni uygulanmıştır. Organik madde (OM) ana işlem olarak $150 \mathrm{~m}^{2}$ uzunluğundaki fidan yetiştirme yastıklarına $2 \mathrm{~m}^{3}, 1 \mathrm{~m}^{3}$ ve $0 \mathrm{~m}^{3}$ (organik madde ilavesi olmayan) olmak üzere farkl 3 doz orman humusu ilave edilerek oluşturulmuştur. Fidan yetiştirme sıklığ (FYS) ise metrekarede; 100, 75, 50 ve 25 fidan olacak şekilde 4 seviyeli olarak uygulanmıştır. Birim alandan SF elde edilmesi konusunda FYS ve OM istatistiki olarak anlamlı $(\mathrm{P}<0,05)$ bulunmuştur. Ortalamaların karşılaştırıldığı Duncan Testi'ne göre, $2 \mathrm{~m}^{3} \mathrm{OM}$ ilave edilen işlem parselinden elde edilen SF adetleri istatistiki olarak anlamlı bulunmuştur. Bu işlem parselinden elde edilen SF adedi 75, 100, 50 ve 25 sıklıkları için sırasıyla; $38,38,33$ ve 17 olarak bulunmuştur. Ancak, $2 \mathrm{~m}^{3}$ organik madde ilave edilen işlem parselinde ilk üç sıklıktan elde edilen SF adedi aynı gurupta yer almış ve istatistiki anlamda birbirinden farksız çıkmıştır. OM ilavesi 1 ve $0 \mathrm{~m}^{3}$ olan işlem parsellerinde ise istatistiki olarak fark çıkmamıştır. Elde edilen verilere göre, fidan yetiştirme yastığının OM içeriği artışına bağlı olarak elde edilen SF adedinin arttığı görülmektedir. Bu nedenle FYS'nin, fidan yetiştirme ortamının verimliliğine göre belirlenmesi daha isabetli olacaktır. Diğer taraftan yüksek sıklıklara oranla düşük sıklıklarda fidan yetiştirmenin daha kolay ve ekonomik olacağı düşüncesiyle, $2 \mathrm{~m}^{3} \mathrm{OM}$ ilavesi olan parsel için 50, 1 ve $0 \mathrm{~m}^{3} \mathrm{OM}$ ilavesi olan işlemler için ise 25 adet FYS önerilmektedir.

Anahtar Kelimeler: Dar Yapraklı Dişbudak, organik madde, fidan yetiştirme sıklığı, kaliteli fidan 


\section{Introduction}

Turkish General Directorate of Forestry has decided to establish industrial plantation with the Narrow-Leaved Ash (Fraxinus angustifolia, Oleacae Vahl.) tree species recently. Plantation areas of ash are generally located in bottomlands. Dens and tall weeds are great problem for establishing successful plantation in these areas. Using the seedlings having a specified height is important for controlling the weeds in a short time. Thusly, cost of the maintenance for cultivars will be reduced. With a greater initial height at planting, seedlings are better able to out-compete weeds than smaller seedlings. This is especially important on sites that are prone to excessive weed competition (Jacobs, 2003). It has been known that nursery techniques related to plant species and cultural maintenance have great importance on achieving of quality seedling (QS). Setting up successful plantations depend on using quality seedling. Root collar diameter (RCD) and height of seedlings are important parameters for determining the QS, but the condition of plantation areas are more important than RCD and seedling height. However having thicker at RCD, higher at length, more fine and thick root amount, bigger root/stem ratio are important factors for determining the QS, the conditions of the forestation areas also have great importance. While the small and bigger root/stem ratios seedlings are important factors for setting up successful plantations in dry regions, using higher and thicker seedlings are very important for competing and getting advantage within a short time against the dens and tall weeds in bottom land conditions. Nowadays, the QS has been defined as objective seedling that is suitable and adaptable for plantation site (Gültekin, 2014).

Generally small sized seedlings have been used for artificial regenerations of Narrow-Leaved Ash (NLA) in Turkey. Planting small seedlings can not tolerate the competition from weeds (Çiçek et all, 2006). Tolay (1978) reported that knowing site conditions of planting sites is a critical prerequisite for determining sapling quality, and carrying out growing trials were important. Be able to grow QS, the seedlings grown in nurseries must have more or less same diameter and height (Tolay, 1994). But getting success depends on providing the seeds from correct seed sources and implementing the homogenous silvicultural techniques (irrigation, fertilizing, sowing, maintenance, and etc.). Organic matter is one of the most important component of the soils. Sources of OM are plants and animals. It has been known that incorporation OM to the soils is being improved the physical and chemical conditions of soils. In a forest nursery, however, root and shoot are both removed. Therefore, organic matter must be either brought in from somewhere else and added to the soil or grown on site as a green manure crop (Warkentin, 1984). Generally morphological characteristics of seedlings are being taken into account for determining the sapling quality, but root collar diameter and height of saplings have been accepted adequate for deciding the sapling quality (Levander, 1976). Similarly Jacobs (2003) indicate that when comparing the morphology of seedlings from a single species, taller seedlings with a larger root collar diameter are probably superior in morphological quality than those with lesser values for these characteristics. Using higher seedlings for reforestation of water-logged bottomlands which has include dens and tall weeds have been seen important due to reducing the cost of maintenance and advantage in competition against to weeds (Tolay, 1983; Çiçek and et all., 2007a; Çiçek and et all., 2011). On the other hand, it was determined that RCD has given the best correlation in the success of plantation (Clark and et all, 2010; Schmidt-Vogt, 1981).

Objective of this study, to obtain the most number of $1+0$ years old and bare-root NLA (Fraxinus angustifolia ssp. oxycarpa Vahl.) seedlings that thicker or equal to $8 \mathrm{~mm}$ at RCD and taller or equal to $75 \mathrm{~cm}$ at shoot height (SH) from a certain unit of seedbed in İzmit Nursery. Due to high and dens weeds in bottomland areas which are subjected to NLA plantations, using relatively higher and ticker seedlings are necessary for establishing successful plantations.

\section{Material and Methods}

\section{Definition of Study Site and Material}

The trial was established in a state-owned nursery located in İzmit, Kocaeli, Turkey $\left(40^{\circ} 46^{\prime} \mathrm{N}\right.$, $29^{\circ} 54^{\prime} \mathrm{E}, 10 \mathrm{~m}$ asl). The nursery has been formed with young alluvial soils with a smooth and 
homogeneous soil structure. The nursery has silty loam, lightly alkaline and lime-free soils. The mean annual rainfall approximately $771 \mathrm{~mm}$, mean annual temperature is $14.5{ }^{\circ} \mathrm{C}$, the mean highest temperature with the $29,2^{\circ} \mathrm{C}$ in august, the mean minimum temperature with $2,8^{\circ} \mathrm{C}$ in january, and the minimum rainfall is being realized with the $36,8 \mathrm{~mm}$ in august according to İzmit Meteorological Station records.

The humus used as OM was provided from the coniferous forest. To determine the various physical and chemical soil properties, soil samples were taken from 0-30 depths after the addition of OM. Samples were air-dried, sieved through a 2-mm screen, and analyzed. Sand, silt, and clay ratios of the samples were determined by the Bouyoucos hydrometer method (Karaöz, 1989). The organic carbon content was found using the Walkey and Black wet digestion method (T.S.E., 1990 b). Soil pH was measured with a glass electrode (1.0:2.5 soil/water), electrical conductivity (soluble salts) was measured in a 1.0:2.5 soil/water mixture, and exchangeable $\mathrm{K}, \mathrm{Na}, \mathrm{Ca}$, and $\mathrm{Mg}$ were determined by atomic absorption spectrophotometry on $1 \mathrm{~mol}^{-1}$ ammonium acetate extracts (Karaöz, 1989). Soil phosphorus $\left(\mathrm{P}_{2} \mathrm{O}_{5}\right)$ was extracted by the Olsen method (sodium bicarbonate), which is recommended for calcareous soils, and $\mathrm{CaCO}_{3}$ was determined with the Scheibler Kalsimeter method (T.S.E., 1990 e.). Total N was determined using a Leco FP-328 elemental N analyzer (Leco Corporation, St. Joseph, Michigan, USA). All soil analyses were done by the Soil Testing Laboratory of Poplar and Fast Growing Trees Research Institute. The results of soil analyses can be seen in Table 1.

\section{Experimental design and treatments}

The factorial experimentation was applied with randomized complete block and split plot design with three replications, in order to test the effects of organic matter content, seedling densities and their interactions on the quality seedling number (QSN). Organic matter was applied as main treatment with the rates of; 0,1 , and $2^{3}$ for the $150 \mathrm{~m}$ length of seedbed. Seedling density was applied as $100,75,50$, and 25 seedlings per $1 \mathrm{~m}^{2}$ seedbed unit.

\section{Measurements and statistical analyses}

Shoot heights and root collar diameters of the whole seedlings were measured in treatment plots. Root collar diameters $(\mathrm{mm})$ were measured at the $2.5 \mathrm{~cm}$ above the ground level using a caliper, and seedling height was measured to the live bud on the stem in $\mathrm{cm}$. Arcsine transformation was performed on the variables of seedlings which has thicker at RCD than $8 \mathrm{~mm}$ and higher than $75 \mathrm{~cm}$. Analyses of variance (ANOVA) were used to evaluate the content of OM and SD effects on the QSN. Differences among treatments were tested at $\alpha=0.05$. The variables analyzed were the mean plot values. Significant differences between variable means were determined by Duncan's New Multiple Range Test (Açıkgöz and Akkaş, 1997).

\section{Preparation of materials and maintenances}

The seeds used in trial were collected from the ash trees which have been grown naturally in İzmit Forest Nursery in October of 2011. Organic matter (humus) was added to seedbeds and mixed with a rotary plow than drilled to five rows. The stratified seeds were hand-sown into the lines in April 2012 to produce one-year old bare-root seedlings. Seedlings were thinned to bring the densities envisaged level when survival was assured 4 weeks after germination. During the vegetation period, following the sowing date, the only treatment given was irrigation and weed control hoeing.

\section{Results}

There is linear increasing for the values of $\mathrm{CaCO}_{3}, \mathrm{OM}, \mathrm{N}, \mathrm{AWC}, \mathrm{Ca}^{++}$and $\mathrm{K}^{+}$with the humus addition (Table 1). 
Table 1. Analyzes results of soils sampled from the depth of $0-30 \mathrm{~cm}$ after the organic matter (humus) addition

\begin{tabular}{|c|c|c|c|c|c|c|c|c|c|c|c|}
\hline \multirow{2}{*}{$\begin{array}{l}\text { Dozes of } \\
\text { Humus }\end{array}$} & \multirow{2}{*}{\begin{tabular}{|c|}
$\mathrm{CaCO}_{3}$ \\
$\%$ \\
\end{tabular}} & \multirow{2}{*}{\begin{tabular}{|c|}
$\mathrm{EC}$ \\
$\mathrm{mS} / \mathrm{cm}$
\end{tabular}} & & \multirow{2}{*}{$\begin{array}{c}\text { OM } \\
\%\end{array}$} & \multirow{2}{*}{$\begin{array}{l}\mathbf{N} \\
\%\end{array}$} & \multirow{2}{*}{$\begin{array}{c}\mathbf{P}_{2} \mathbf{O}_{5} \\
\mathbf{p p m}\end{array}$} & \multirow{2}{*}{\begin{tabular}{|c|} 
AWC \\
$\%$
\end{tabular}} & \multicolumn{4}{|c|}{ Exchangeable cations } \\
\hline & & & & & & & & $\underset{\mathrm{me} / 100 \mathrm{~g}++}{\mathrm{C}}$ & $\begin{array}{c}\mathrm{Mg}++ \\
\mathrm{me} / 100 \mathrm{~g}\end{array}$ & $\begin{array}{c}\mathrm{K}+ \\
\mathrm{me} / \mathbf{1 0 0 g}\end{array}$ & $\begin{array}{c}\mathrm{Na}+ \\
\mathrm{me} / 100 \mathrm{~g}\end{array}$ \\
\hline $\mathrm{Om} \%$ & & & 7.73 & 5.31 & 0.10 & 8.77 & 18.79 & & & 97.80 & ו \\
\hline $1 \mathrm{~m}^{3} / 1$ & 0.69 & & 7.83 & 7.27 & 0.14 & 8.73 & 19.98 & 46 & & 58 & 7.11 \\
\hline $2 m^{3} / 1$ & & & & & & & 21.32 & & & & r \\
\hline Pure Humus & 21 & 2.05 & 6.82 & 43.81 & 0.89 & 12.49 & & 3042.25 & 159.41 & 2129.00 & 83.32 \\
\hline
\end{tabular}

$\mathrm{CaCO}_{3}$ : Calcium Carbonate, EC: Electrical Conductivity, pH: Soil acidity, OM: Organic Matter, N: Nitrogen, $\mathrm{P}_{2} \mathrm{O}_{5}$ : Phosphorus, AWC: Available Water Content, Ca++: Calcium, Mg++: Magnesium, K+: Potassium, Na+: Sodium

Treatment parcels incorporated organic matter exhibited significantly greater quality seedling number than control $(\mathrm{P}<0.05)$. Highest QSN was obtained from highest rate of organic matter content (OMC) parcels.

The QSN obtained were 30, 21 and 8 for the OMC of $8.78(\%), 7.27(\%)$ and $5.71(\%)$ respectively not to consider the SD (Fig. 1). Similarly the QSN was affected by seedling density. The highest QSN was obtained from the density of 75 per square meter. The QSN obtained for the densities of 75, 50, 100 and 25 were 22, 21, 18 and 14 respectively not to consider the OMC (Fig. 2). We also observed a significant interaction effect of OMC and SD on the QSN ( $\mathrm{P}<0.05$; Fig. 3). Highest quality seedling number was obtained from the highest organic matter content $(8,78 \%)$ treatment plots. The QSN were $38,38,33$ and 17 for the densities of $75,100,50$ and 25 respectively. There were no significant differences among the densities of 75, 100 and 50 in terms of quality seedling numbers. That is why, the lowest density can be recommended.

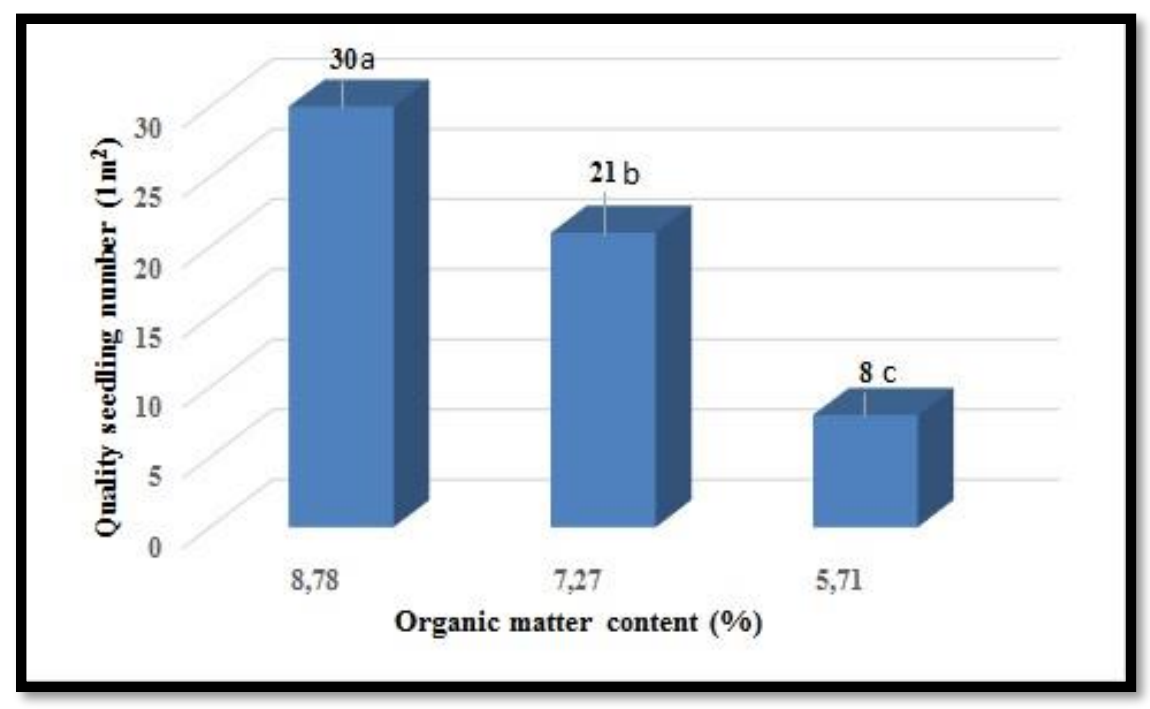

Figure 1. Quality seedling $\left(1 \mathrm{~m}^{2}\right)$ according to organic matter content $(\%)$ 




Figure 2. Quality seedling $\left(1 \mathrm{~m}^{2}\right)$ according to seedling density $\left(1 \mathrm{~m}^{2}\right)$

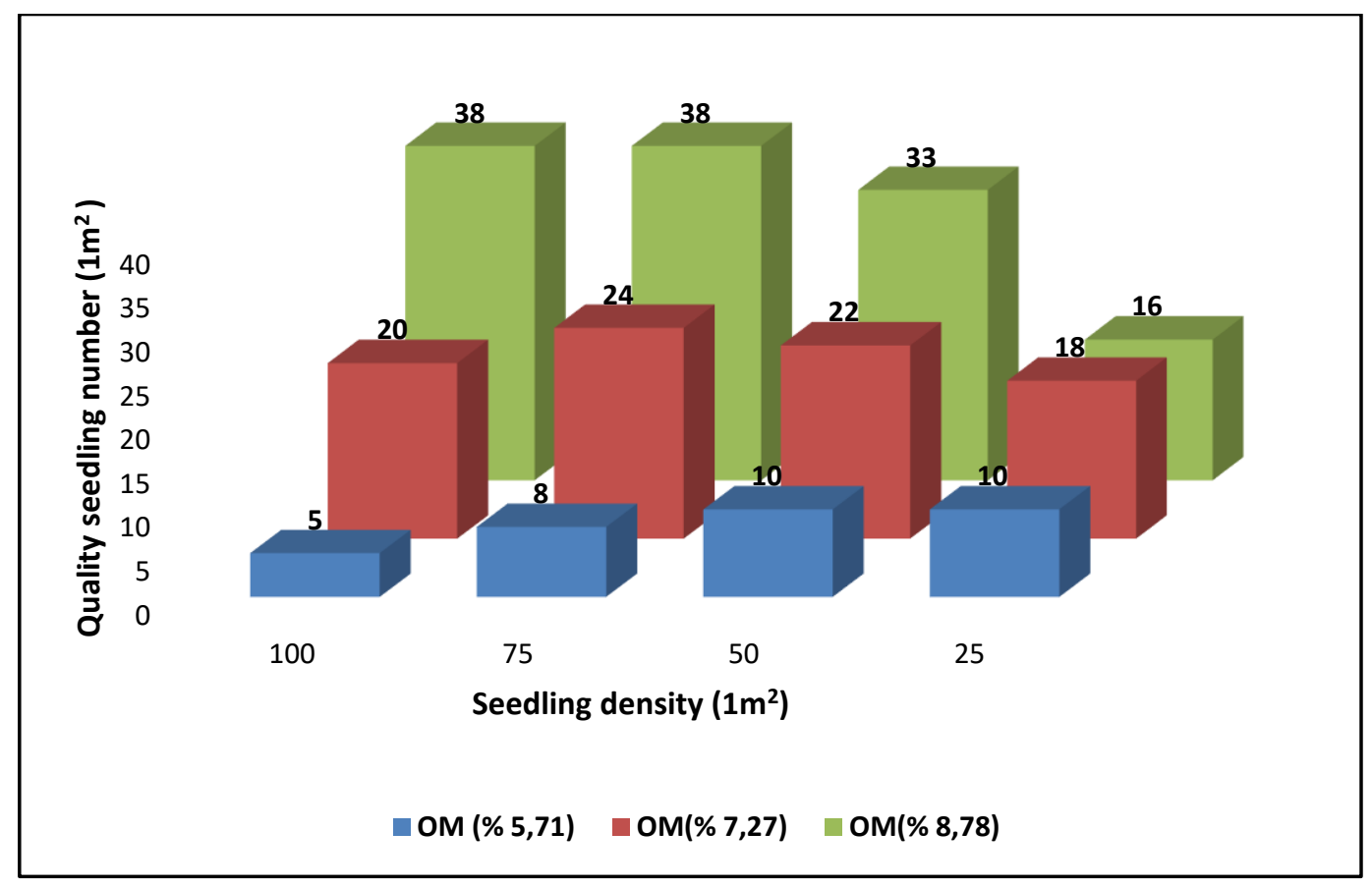

Figure 3. Distribution of quality seedling $\left(1 \mathrm{~m}^{2}\right)$ according to seedling density $\left(1 \mathrm{~m}^{2}\right)$ and organic matter content $(\%)$.

\section{Discussion}

It was obviously seen that when OMC increased, QSN also increased (Fig. 1). It is known that to incorporate OM to the soil, can ameliorate the chemical and physical properties of the soil. While SD increased in lower organic matter content (5.71\%), the number of quality seedlings decreased (Fig. 3). Similarly Barham (1980) noted that as seedbed densities increased, seedling sizes generally decreased and cull percentages increased. Driessche (1980) stressed that increased size may give seedlings an advantage on difficult outplanting sites, such as those with heavy brush or severe animal browsing. When OMC increased, producing capability of quality seedling increased in high seedling densities (Fig.3). Nutrient availability may be affected by soil pH and organic matter content (Driessche, 1980). Due to organic matter decomposed slowly, nutrients which seedlings needed for growing can be 
provided permanently during the growth period. Thusly effective growth can be possible. Weiser (1970) emphasized that frequent light fertilizations will provide more consistent levels of nutrition for seedlings when compared to less frequent heavy applications. Duryea (1984) explained that seventeen elements are essential to plant growth and three of them carbon, hydrogen, and oxygen are absorbed from the atmosphere or from water. He indicated that the remaining 14 are taken up from the soil. To provide the nutrients within a balanced way which seedlings needed is quite difficult. For this reason, adding organic matter to seedbeds is necessary in nurseries which bare root seedlings are being produced.

\section{Conclusion}

Hardwood tree species' seedlings generally are being produced as bare root. Because of lifting with root and transplanting to the plantation areas, organic matter content is continually getting decreased. It is necessary adding the organic matter regularly which was carried out and diminished by lifting and transplanting of seedlings. Incorporation of organic matter to the soil can increase the soil productivity and improve the physical and chemical conditions of soils. It was understood from this study that seedling density can be differed according to organic matter content of seedbed. Before deciding the seedling density in nurseries, productivity of seedbed should be considered.

\section{References}

Açıkgöz, N. ve Akkaş, M. E. 1997. TARİST: Veri Tabanına Dayalı bir Bio İstatistik Paketi. "Araştırma sempozyumu bildirisi. DİE - 24-26 Kasim Ankara.

Barham, R.O., 1980. Effects of Seedbed Density on Nursery-Grown Cherrybark Oak Research Forester, Nursery Research, International Paper Company Natchez, Miss. Forest Research Center

Clark, S. L., C. J. Schweitzer, S. E. Schlarbaum, L. D. Dimov, and F. V. Hebard. 2010. Nursery quality and firstyear response of American chestnut (Castanea dentata) seedlings planted in the southeastern United States. Tree Planters' Notes, 53:13-

Çicek E, Cicek N, Tilki F, 2011. Four-year field performance of Fraxinus angustifolia Vahl. and Ulmus laevis Pall. Seedlings grown at different nursery seedbed densities. Research Journal of Forestry, 5: 89-98.

Cicek, E., Cicek, N., Bilir, N. 2007a. Effects of Seedbed Density on One-Year-Old Fraxinus Angustifolia Seedling Characteristics and Outplanting Performance. New Forests, 33 (1), 81-91.

Çiçek E, Yllmaz M, 2006. Effect of seedbed density on morphological characteristics and field performance of Ulmus leavis seedlings. Journal of Balkan Ecology, 9(2), 167-173.

Duryea, M. L. 1984. In: Forest nursery Duryea and T.D. Landis, eds), p. 143-164 Martinus Nijhof /Dr. W. Junk publishers The Hague/Boston/Lancester, for Forest Res Lab. Oreg. State Univ.

Gültekin, H.C. 2014. Fidan Üretim Teknikleri. T.C. Orman ve Su İşleri Bakanlığı, Orman Genel Müdürlüğü, Kavak ve Hızlı Gelişen Orman Ağaçları Araştırma Enstitüsü Müdürlüğü, Müdürlük Yayın No:271, Çeşitli Yayınlar Serisi No: 26, İzmit.

Jacobs, D.F. 2003. Nursery production of hardwood seedlings. FNR-212. West Lafayette, IN: Purdue University Cooperative Extension Service. 8 p.

Karaöz, M. Ö. 1989. Toprakların Bazı Kimyasal Özelliklerinin (Ph, Karbonat, Tuzluluk, Organik Madde, Total Azot, Yararlanılabilir Fosfor) Analiz Yöntemleri. İ.Ü. Orman Fakültesi Dergisi. Seri B, Cilt 39, Sayı 3: 6482.

Lavender, D.P. and B.D. Cleary. 1974. Coniferous seedling production techniques to improve seedling establishment. pp. 177-180. In Proc. North American containerized forest tree seedling symposium. (R.W. Tinus, W.I. Stein, and W.E. Balmer eds) Great Plains Agricultural Publication No. 68.

Tolay, U. 1978. Ağaçlandırmada Kaliteli Fidan Sorunu. Kavak ve Hızlı Gelişen Yabancı Tür Orman Ağaçları Araştırma Enstitüsü Dergisi. S:42-46

Tolay, U., 1983. Hendek Orman Fidanlığında Uludağ Göknarı (Abies bormülleriana Mattf.)'ın Yetiştirme Tekniği İle Fidan Kalitesi ve Dikim Başarısı Arasındaki İliş̧kiler Üzerine Araştırmalar. Kavak ve Hızlı Gelişen Yabancı Tür Orman Ağaçları Araştırma Enstitüsü, O.D.C.: 232.321, İzmit. 
Tolay, U. 1994. Yapraklı Tür Orman Ağaçları Fidan Üretim Tekniği. Kavak ve Hızlı Gelişen Tür Orman Ağaçları Araştırma Enstitüsü Dergisi. Dergi No: 21, S:1-19

T.S.E., 1990 b. Topraklar - Organik Madde Tayini. Soils - Determination of Organic Matter. TS8336/Nisan 1990. UDK 631,41., $4 \mathrm{~s}$.

T.S.E., 1990 c. Topraklar - Toplam Azot Tayini. Soils - Determination of Total Nitrogen. TS 8337/Nisan 1990. UDK $631.41,4 \mathrm{~s}$.

T.S.E., 1990 e. Topraklar - Fosfor Tayini (Olsen ve Ark. Metodu). Soils - Determination of Phosphorus (Olsen et al. method.) TS 8340/Nisan 1990. UDK $631.41,5 \mathrm{~s}$.

Schmidt-Vogt, H. 1981. Morphological and physiological characteristics of planting stock: present state of research and research tasks for the future. Pages 433-446 in Proc., IUFRO XVII World Congress. Freiburg i. Br., Federal Republic of Germany.

Warkentin B. P. 1984. Physical Properties of Forest-Nursery Soils: Relation to Seedling Growth. P:53-61. Forest Nursery Manual: Chapter 6, Production of Bareroot Seedlings. Nursery Technology Cooperative Department of Forest Science Oregon State University Corvallis, Oregon 97331 U.S.A.

Wakeley, P.C. 1954. Planting the southern pines. U. S. D. A. Forest Service Agricultural. Monograph 18. 233p.

Van den Driessche. R. 1980. Health, vigour and quality of conifer seedlings in relation to nursery soil fertility. Pages 100-120 in Proc., North American forest tree nursery soils workshop (L. P. Abrahamson and D. H. Bickelhaupt, eds.). State Univ. New York, Coll. Environ. Sci. and Forestry, Syracuse.

Weiser, C. J. 1970. Cold resistance and injury in woody plants. Science 169:1269-1277. 98 